\title{
IUPAC-IUB Commission on Biochemical Nomenclature
}

\author{
Symbols for Amino-Acid Derivatives and Peptides ${ }^{1}$
}

Recommendations (1971)

The revised Tentative Rules published by CBN in 1966 (1) were an attempt to achieve a broad systematization of various types of abbreviated notation already in use [e.g., Brand \& Edsall (1947) Annu. Rev. Biochem.; Report of the Committee on Abbreviations of the American Society of Biological Chemists, 18 December 1959; Report of the Committee on Nomenclature of the European Peptide Symposium (1963) pp. 261-269, Pergamon Press, Oxford; 'Tentative Rules for Abbreviations and Symbols of Chemical Names of Special Interest in Biological Chemistry' (2)]. They sought to reconcile the needs of the protein chemist, i.e., indication of amino-acid sequences, with those of persons concerned more with the chemical reactions of proteins and the synthesis of polypeptides, i.e., the need for conveying more detailed chemical information in abbreviated form.

Recent progress in the field of peptide synthesis and in the chemical modification of proteins has made necessary a revision of these Tentative Rules. This revision has been aided by the work of an expert group consisting of J. S. Fruton, B. S. Hartley, R. R. Porter, J. Rudinger, R. Schwyzer and G. T. Young. They are greatly indebted to many colleagues, notably W. H. Stein, for helpful suggestions.

\section{General Considerations}

\section{1}

The symbols chosen are derived from the trivial names or chemical names of the amino acids and of chemicals reacting with amino acids and polypeptides. For the sake of clarity, brevity and listing in tables, the symbols for amino-acid residues have been, wherever possible, restricted to three letters, usually the first letters of the trivial names.

${ }^{1}$ Document of the IUPAC-IUB Commission on Biochemical Nomenclature (CBN), approved by $C B N$ in May 1971, and published by permission of the International Union of Pure and Applied Chemistry and the International Union of Biochemistry. Reprints may be obtained from Waldo E. Cohn, Director, NAS-NRC Office of Biochemical Nomenclature, Oak Ridge National Laboratory, Box Y, Oak Ridge, Tenn. 37830, U.S.A.

Comments on and suggestions for future revisions of these Recommendations may be sent to any member of CBN: O. Hoffmann-Ostenhof (Chairman), W. E. Cohn (Secretary), A. E. Braunstein, B. L. Horecker, P. Karlson, B. Keil, W. Klyne, C. Liébecq, E. C. Webb, W. J. Whelan.
1.2

The symbols represent not only the names of the compounds but also their structural formulae.

\section{3}

The amino-acid symbols by themselves represent the amino acids. The use of the symbols to represent the free amino acids is not recommended in textual material, but such use may occasionally be desirable in tables, diagrams or figures. Residues of amino acids are represented by addition of hyphens in specific positions as indicated in Section 3.

\section{4}

Heteroatoms of amino-acid residues (e.g., $\mathrm{O}^{3}$ and $\mathrm{S}^{3}$ of serine and cysteine respectively, $\mathrm{N}^{6}$ of lysine, $\mathrm{N}^{2}$ of glycine etc.) do not explicitly appear in the symbol; such features are understood to be encompassed by the abbreviation.

\section{5}

Amino-acid symbols denote the $\mathrm{L}$ configuration unless otherwise indicated by $\mathrm{D}$ or DL appearing before the symbol and separated from it by a hyphen. When it is desired to make the number of amino-acid residues appear more clearly, the hyphen between the configurational prefix and the symbol may be omitted (see 6.3.1.1 et seq.). (Note: The designation of an amino-acid residue as DL is inappropriate for compounds having another amino-acid residue with an asymmetrical centre.)

\section{6}

Structural formulae of complicated features may be used along with the abbreviated notation wherever necessary for clarity.

\section{7}

All symbols listed below are to be printed or typed as one capital letter followed by two lower-case letters, e.g., Gln, not GLN or gln or GIN or gIN, regardless of position in a sentence or structure. However, when used for purposes other than to represent an amino-acid residue (e.g., to designate a 
genetic factor), three lower-case italic letters (i.e., $g l n$ ) should be used.

\section{Symbols for Amino Acids}

\subsection{Common amino acids}

$\begin{array}{llll}\text { Alanine } & \text { Ala } & \text { Leucine } & \text { Leu } \\ \text { Arginine } & \text { Arg } & \text { Lysine } & \text { Lys } \\ \text { Asparagine } & \text { Asn } & \text { Methionine } & \text { Met } \\ \text { Aspartic acid } & \text { Asp } & \text { Phenylalanine } & \text { Phe } \\ \text { Cysteine } & \text { Cys } & \text { Proline } & \text { Pro } \\ \text { Glutamic acid } & \text { Glu } & \text { Serine } & \text { Ser } \\ \text { Glutamine } & \text { Gln }^{2} & \text { Threonine } & \text { Thr } \\ \text { Glycine } & \text { Gly } & \text { Tryptophan } & \text { Trp } \\ \text { Histidine } & \text { His } & & \text { (not Try) } \\ \text { Isoleucine } & \text { Ile } & \text { Tyrosine } & \text { Tyr } \\ & & \text { Valine } & \text { Val }\end{array}$

\subsection{Less-common amino acids}

Symbols for less-common amino acids should be defined in each publication in which they appear. The following principles and notations are recommended.

\subsubsection{Hydroxyamino acids.}

\begin{tabular}{|c|c|c|c|}
\hline \multirow{3}{*}{ 5-Hydroxylysine } & \multirow{3}{*}{$5 \mathrm{Hyl}$} & \multicolumn{2}{|c|}{ Preferred alternatives } \\
\hline & & Lys $(5 \mathrm{OH})$ & Lys \\
\hline & & or & $5 !$ \\
\hline 3-Hydroxyproline & 3Нур & $\operatorname{Pro}(3 \mathrm{OH})$ & $\mathrm{OH}$ \\
\hline & & or & $\begin{array}{l}\left.3\right|_{\text {Pro }}\end{array}$ \\
\hline 4-Hydroxyproline & 4Hyp & Pro(4OH) & Pro \\
\hline & & or & 4 \\
\hline
\end{tabular}

2.2.2 allo-Amino acids.

allo-Isoleucine aIle

allo-Hydroxylysine $\quad a \mathrm{Hyl} \quad a \mathrm{Lys}(5 \mathrm{OH})$ or $a \mathrm{Lys}$

2.2.3 'Nor' and 'homo' amino acids. 'Nor' (e.g., in norvaline) is not used in its accepted sense (denoting a lower homologue) but to change the trivial name of a branched-chain compound into that of a straightchain compound (compare with 'iso', paragraph 2.1). 'Nor' should therefore be treated as part of the trivial name without special emphasis. 'Homo', used in the

${ }^{2}$ Asparagine and glutamine may also be denoted as $\operatorname{Asp}\left(\mathrm{NH}_{2}\right)$ or Asp and Glu( $\left.\mathrm{NH}_{2}\right)$ or Glu, respectively, if ${ }_{\mathrm{NH}_{2}}$

necessary (as when the $\mathrm{NH}_{2}$ is substituted, or its removal or modification is under discussion). See 4.2.

Glx may be used when the residue denoted could be 'glutamic acid or glutamine'; similarly, Asx for 'aspartic acid or asparagine'. sense of a higher homologue, may also be incorporated into the trivial name.

$\begin{array}{llll}\text { Norvaline } & \mathrm{Nva} & \text { Homoserine } & \text { Hse } \\ \text { Norleucine } & \mathrm{Nle} & \text { Homocysteine } & \text { Hcy }\end{array}$

2.2.4 Higher unbranched amino acids. The functional prefix 'amino' is included in the symbol as the letter ' $A$ ', diamino as ' $\mathrm{A}_{2}{ }^{3}$. The trivial name of the parent acid is abbreviated to two letters. The word 'acid' ('-säure' etc.) is omitted from the symbol as carrying no significant information. Unless otherwise indicated, single groups are in the 2-position, two amino groups in the 2- and terminal positions (monocarboxylic acids) or 2- and 2'-positions (dicarboxylic acids). The location of amino groups in positions other than these is shown by appropriate prefixes.

\section{Examples:}

2-Aminobutyric acid

2-Aminoadipic acid

2-Aminopimelic acid

2,4-Diaminobutyric acid

2,2'-Diaminopimelic acid

2,3-Diaminopropionic acid

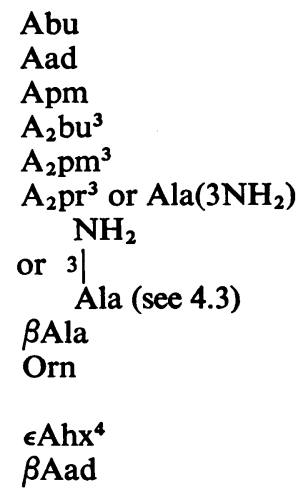

$\beta$-Alanine

Ornithine (2,4-diaminovaleric acid)

6-Aminohexanoic acid

3-Aminoadipic acid

BAad

2.2.5 $N^{2}$-Alkylated amino acids. $N^{2}$-Alkylamino acids are becoming more and more common (e.g., in the large group of depsipeptides). This justifies special symbols.

\section{Examples:}

$N$-Methylglycine (sarcosine) (see 6.2) MeGly or Sar $N$-Methylisoleucine

MeIle

$N$-Methylvaline etc.

MeVal etc.

$N$-Ethylglycine etc.

EtGly etc.

${ }^{3}$ The symbols for diamino compounds previously (1) utilized the letter ' $D$ ' for 'diamino'. However, the overuse of ' $D$ ' as the initial letter for many compounds beginning with 'di' (and of ' $T$ ' for 'tri' and 'tetra'), in addition to the fact that standard chemical symbolism utilizes subscript numerals for multipliers, leads to the proposal that diamino should be represented by $A_{2}$. This eliminates the ambiguity attached to ' $D$ ' and makes more clear the chemical relationship between the diamino and monoamino derivatives. It is in keeping with the increasing use of $\mathrm{Me}_{2} \mathrm{SO}$ instead of DMSO and of $\mathrm{Me}_{3} \mathrm{Si}$ - in place of TMS-, and with the earlier proposal of $\mathrm{H}_{4}$ for tetrahydro (4).

${ }^{4}$ Recommended in place of the previous (1) $\epsilon \mathrm{Acp}$, in which 'cp' for caproic may be confused with capric and caprylic. 


\subsection{Non-amino-acid residues linked to peptides}

For residues of muramic acid, sialic acid, neuraminic acid etc. linked to amino-acid residues, as in bacterial-cell-wall components, the symbols Mur, $\mathrm{Sia}, \mathrm{Neu}$ etc. (preceded by Ac if $N$-acetylated) are recommended. The symbols for sugar residues (Glc, Gal etc.) (2) and nucleotides (Ado, Cyd etc.) (3) may also be used.

\section{Amino-Acid Residues}

The links between residues have frequently been shown by peptide chemists as full points (periods, dots: $\cdot$ ) and by carbohydrate chemists (generally) as short strokes (dashes, hyphens: -). At times, special symbols have been used $(>$ or $\rightarrow$ ) to show the direction of what is in all cases an unsymmetrical link (peptide or glycoside).

For consistency and ease of typing as well as economy in printing, the hyphen, representing the peptide bond, should be the standard connecting symbol (2).

The simple usage by which Gly-Gly-Gly stands for glycylglycylglycine appears to involve the employment of the same three letters (Gly) for three different residues or radicals $(b),(c),(d)$ below. However, if the dashes or hyphens are considered as part of each symbol, we have four distinct forms, for the free amino acid and the three residues, viz.:

(a) Gly $=\mathrm{NH}_{2}-\mathrm{CH}_{2}-\mathrm{CO}_{2} \mathrm{H}$ the free amino

(b) Gly- = $\mathrm{NH}_{2}-\mathrm{CH}_{2}-\mathrm{CO}-\quad$ the left-hand unit

(c) -Gly- = - NH- $-\mathrm{CH}_{2}-\mathrm{CO}-$ the middle unit

(d) $-\mathrm{Gly}=-\mathrm{NH}-\mathrm{CH}_{2}-\mathrm{CO}_{2} \mathrm{H}$ the right-hand unit

For peptides, a distinction may be made between the peptide, e.g., Gly-Glu (shown without dashes at the ends of the symbols), and the sequence, e.g., -Gly-Glu- (shown with dashes at the ends of the symbols).

\subsection{Lack of hydrogen on the 2-amino group}

The 2-amino group is understood to be at the lefthand side of the symbol when hyphens are used, and - in special cases - at the point of the arrow when arrows are used to indicate the direction of the peptide bond (-CO $\rightarrow \mathrm{NH}-$, $-\mathrm{NH} \leftarrow \mathrm{CO}-$ ). (For substitution for 2-amino hydrogen, see 4.1.)

Examples:

$$
\begin{aligned}
& \text {-Gly: } \quad-\mathrm{HN}-\mathrm{CH}_{2}-\mathrm{CO}_{2} \mathrm{H} \\
& >\text { Gly or } \perp_{\text {Gly: } \quad}>\mathrm{N}-\mathrm{CH}_{2}-\mathrm{CO}_{2} \mathrm{H} \\
& \text {-Ala: } \\
& \stackrel{\stackrel{\mathrm{C}}{\mathrm{C}} \mathrm{H}_{3}}{-\mathrm{HN}-\mathrm{CH}-\mathrm{CO}_{2} \mathrm{H}} \\
& >\text { Ala or } \perp \text { Ala: }
\end{aligned}
$$

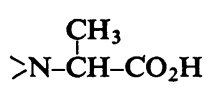

\subsection{Lack of hydroxyl on the 1-carboxyl group}

The 1-carboxyl group is understood to be on the right-hand side of the symbol when hyphens are employed and - in such special cases as 6.3.1.3 - at the tail of the arrow when arrows are used to indicate the direction of the peptide bond $(-\mathrm{CO} \rightarrow \mathrm{NH}-$, $-\mathrm{NH} \leftarrow \mathrm{CO}-$ ).

\section{Example:}

$$
\text { Gly-: } \quad \mathrm{H}_{2} \mathrm{~N}-\mathrm{CH}_{2}-\mathrm{CO} \text { - }
$$

It is generally convenient to use the same abbreviated formula for a polypeptide no matter what its state of ionization. To show that a peptide is acting as a cation or anion, the amino-terminal and carboxylterminal ends of the peptide are amplified with $\mathrm{H}$ and $\mathrm{OH}$ respectively (I); these may be modified to show the appropriate state of ionization (II or III).

$$
\begin{gathered}
\text { H-Gly-Val-Thr-OH or Gly-Val-Thr } \\
{ }^{+} \mathbf{H}_{2} \text {-Gly-Val-Thr-OH or }{ }^{+} \text {HGly-Val-Thr } \\
\text { H-Gly-Val-Thr-O- }
\end{gathered}
$$

3.3 Lack of hydrogen on amino, imino, guanidino, hydroxyl and thiol functions in the side chain

(For substitution in such positions, see 4.2.)

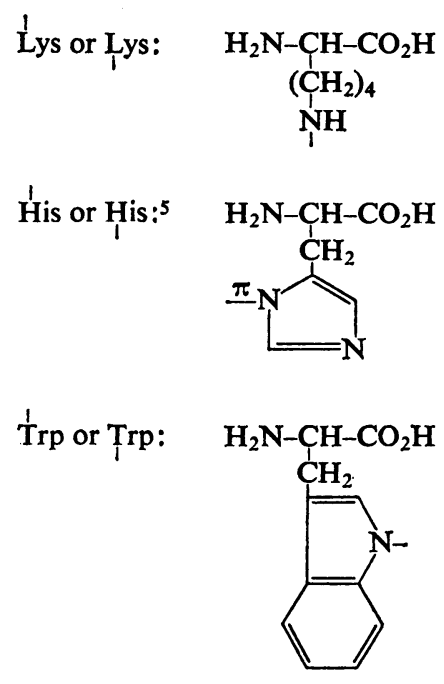

\footnotetext{
${ }^{5}$ The prolonged and well-entrenched ambiguity in the nomenclature of the $N$-methylhistidines (the chemist's $\mathrm{N}-1$ being the biochemist's $\mathrm{N}-3$ and vice versa) leads to the proposal that a new trivial system for designating these substances is necessary. It is therefore proposed that the imidazole $\mathbf{N}$ nearer the alanine residue be designated pros (symbol $\pi$ ) and the one farther tele (symbol $\tau$ ), to give the following names and symbols: prosmethylhistidine or $N^{\pi}$-methylhistidine, $\operatorname{His}(\pi \mathrm{Me})$; telemethylhistidine or $N^{*}$-methylhistidine, $\mathrm{His}(\tau \mathrm{Me})$. See also.4.2, final_example.
} 


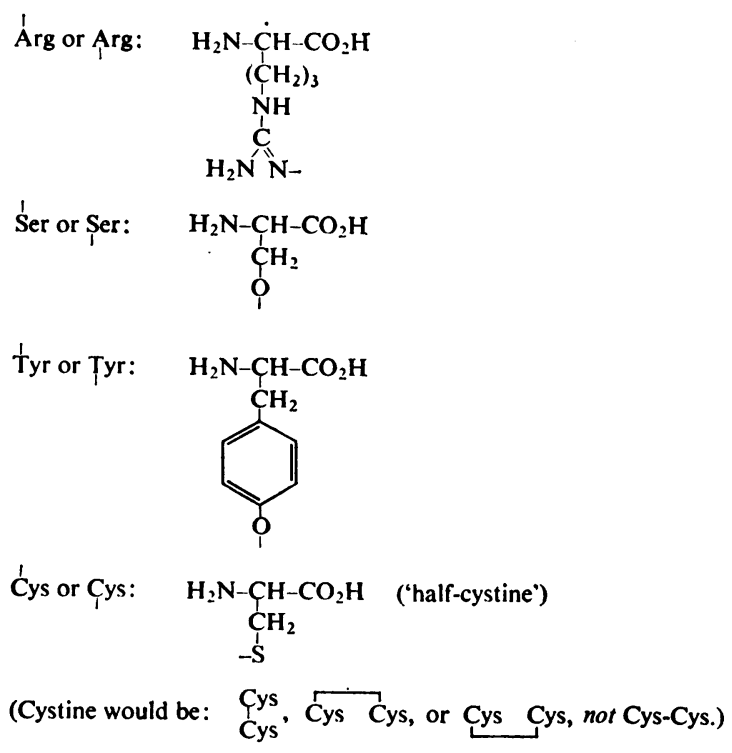

3.4 Lack of hydroxyl on carboxyl groups in the side chain<smiles>CC(=O)CCC(N)C(=O)O</smiles>

\subsection{Cyclic derivatives of amino acid residues}

For the special cases of the residues derived from pyrrolid-2-one-5-carboxylic acid (also known as pyroglutamic acid) and from homoserine lactone, the following are recommended:

$$
\begin{array}{cc}
\text { [Glu- or > Glu- (not PCA) } & \begin{array}{l}
\mathrm{OC}-\left(\mathrm{CH}_{1}\right)_{2} \\
\mathrm{HN}-\mathrm{CH}-\mathrm{CO}-
\end{array} \\
-\mathrm{Hse} & \begin{array}{l}
\left(\mathrm{H}_{2} \mathrm{C}_{2}-\mathrm{O}\right. \\
\text { or -Hse> }
\end{array} \\
-\mathrm{HN}-\mathrm{CH}-\mathrm{CO}
\end{array}
$$

\section{Substituted Amino Acids}

4.1 Substitution in the 2-amino and 1-carboxyl groups

This follows logically from 3.1 and 3.2. The following examples will make the usage clear. (See also 6.2.)

$\begin{array}{ll}N \text {-Acetylglycine } & \text { Ac-Gly } \\ \text { Glycine ethyl ester } & \text { Gly-OEt } \\ N^{2} \text {-Acetyllysine } & \text { Ac-Lys } \\ \text { Serine methyl ester } & \text { Ser-OMe } \\ O^{1} \text {-Ethyl } N \text {-acetylglutamate } & \text { Ac-Glu-OEt } \\ \text { Isoglutamine } & \text { Glu-NH } \\ O^{1} \text {-Methyl hydrogen aspartate } & \text { Asp-OMe } \\ N \text {-Ethyl- } N \text {-methylglycine } & \text { Et-MeGly, } \\ & \mathrm{Et}^{-} \\ & \mathrm{Me}^{-} \text {Gly, } \mathrm{Me}^{\perp_{\text {Gly }}}\end{array}$

\subsection{Substitution in the side chain}

Side-chain substituents may be portrayed above or below the amino-acid symbol (see 3.3 and 3.4), or by placing the symbol for the substituent in parenthesis immediately after the amino-acid symbol.

The use of parentheses should be reserved for a single symbol denoting a side-chain substituent. When a more complex substituent is involved, it is recommended that the vertical stroke and the twoline abbreviation be used (5). In general, the one-line abbreviation should be used only when the structure of a substituted peptide is given in textual material.

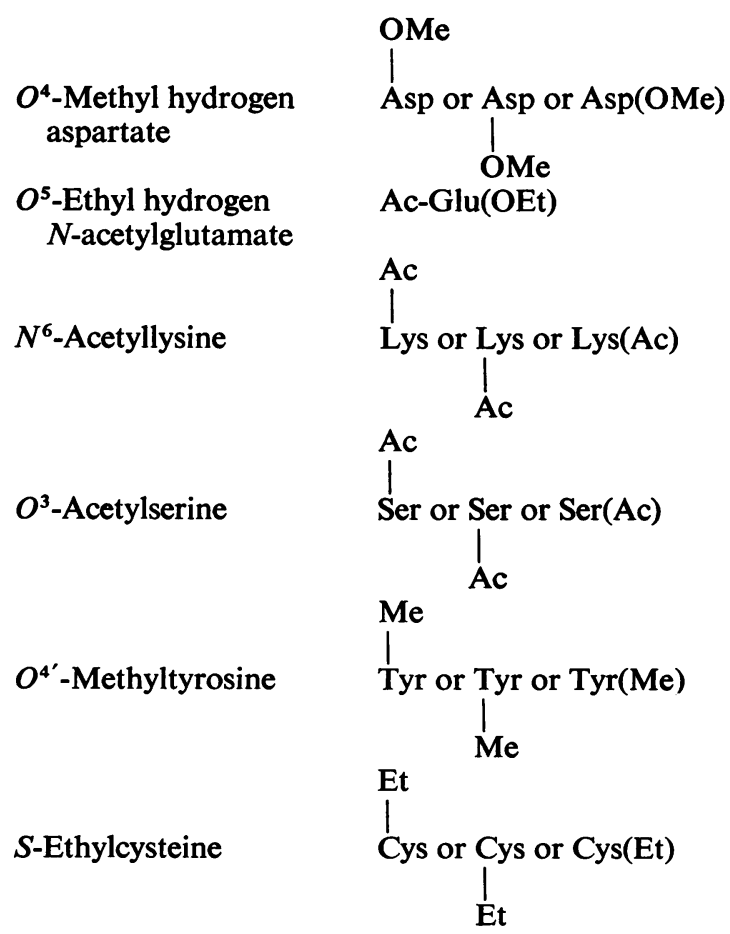




\section{$S$-Sulfocysteine ( $S$-cysteinesulfonic acid)}

Cysteinesulfenic acid

Cysteinesulfinic acid

Cysteic acid

(3-sulfoalanine)

S-Cyanocysteine

Methionine sulfoxide

$O^{3}$-Phosphonoserine (phosphoserine)

$N^{\tau}$-Methylhistidine ${ }^{5}$

(see 3.3) (telemethylhistidine)

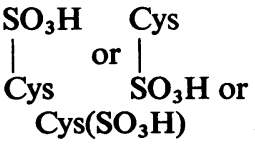

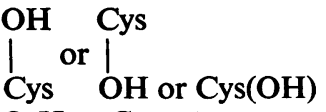

$\left.\right|_{\mathrm{Cys}} ^{\mathrm{O}_{2} \mathrm{H}}$ or $\mathrm{OH}_{2}$ or $\mathrm{Cys}\left(\mathrm{O}_{2} \mathrm{H}\right)$

$\mathrm{O}_{3} \mathrm{H}$ Cys<smiles>CC(O)O[GeH3]</smiles>
$\mathrm{Cys}\left(\mathrm{O}_{3} \mathrm{H}\right)$

$!_{\text {Cys }}^{\mathrm{CN}}$ or $\mathrm{Cys}$ or $\mathrm{Cys}(\mathrm{CN})$ O<smiles>COCCO</smiles><smiles>O[14CH2]O[14CH2]O[14CH2]O</smiles>

P Ser or Ser or $\operatorname{Ser}(\mathbf{P})$<smiles>C[PH]</smiles>

$\mathrm{Me}$

$\pi$

His or His or $\mathrm{His}(\tau \mathrm{Me})$<smiles>C[14CH3]</smiles>

similarly for $N^{\pi}$-substitution (prosmethylhistidine)

\subsection{Substitution on carbon side chain}

This may use the same convention as in 4.2 , with the addition of locant numerals where necessary, e.g.:

3-Nitrotyrosine

$\mathrm{NO}_{2}$

2,3-Diaminopropionic acid (see 2.2.4) (3-aminoalanine)

Diiodotyrosine

3|

Tyr or Tyr or $\operatorname{Tyr}\left(3 \mathrm{NO}_{2}\right)$ 3| $\mathrm{NO}_{2}$

$\underset{\text { Ala }}{\mathrm{NH}_{2}} \stackrel{\mathrm{Ala}}{\mathrm{NH}_{2}}$ or $\operatorname{Ala}\left(3 \mathrm{NH}_{2}\right)$

$\operatorname{Tyr}\left(\mathbf{I}_{2}\right)$

\section{Symbols for Substituents}

Groups substituted for hydrogen or for hydroxyl may be indicated either by their structural formulae or by symbols or by combinations of both, e.g.:

Benzoylglycine (hippuric -CO-Gly or $\mathrm{C}_{6} \mathrm{H}_{5} \mathrm{CO}-\mathrm{Gly}$ acid)

or ${ }^{6} \mathrm{Bz}-\mathrm{Gly}$ or

PhCO-Gly

Glycine methyl ester

Trifluoroacetylglycine

$\mathrm{Gly}_{-} \mathrm{OCH}_{3}$ or Gly-OMe

$\mathrm{CF}_{3}$ CO-Gly

Suggestions for symbols designating substituent (or protecting) groups common in polypeptide and protein chemistry follow.

\section{$5.1 \mathrm{~N}$-Substituents (protecting groups) of the urethane} type

Benzyloxycarbonyl-

p-Nitrobenzyloxy-

Z- or Cbz-

carbonyl-

$p$-Bromobenzyloxy- $\quad \mathrm{Z}(\mathrm{Br})-$

carbonyl-

p-Methoxybenzyloxy- $\quad \mathrm{Z}(\mathrm{OMe})-$

carbonyl-

p-Methoxyphenylazo-

benzyloxycarbonyl-

p-Phenylazobenzyl-

oxycarbonyl-

$t$-Butoxycarbonyl-

Cyclopentyloxycarbonyl- Poc- or $c$ PeOCO-

\subsection{Other $N$-substituents}

Acetyl-

Benzoyl- $\left(\mathrm{C}_{6} \mathrm{H}_{5}-\mathrm{CO}-\right)$

Ac-

${ }^{2} \mathrm{CH}_{2}-$ or ${ }^{6} \mathrm{Bzl}$

Benzylthiomethyl- $\quad \mathrm{PhSCH}_{2}-$ or Btm-

Carbamoyl-

$\mathrm{NH}_{2} \mathrm{CO}$ - (preferred to $\mathrm{Cbm})$

1-Carboxy-2-nitrophenyl- ${ }^{7} \mathrm{Nbs}-$ 5-thio-

3-Carboxypropionyl- Suc$\left(\mathrm{HO}_{2} \mathrm{C}-\mathrm{CH}_{2}-\mathrm{CH}_{2}-\mathrm{CO}-\right)^{8}$

Dansyl- (5-dimethyl- Dnsaminonaphthalene-1sulfonyl)

Dinitrophenyl- $\quad{ }^{9} \mathrm{~N}_{2}$ ph- or Dnp

Formyl-

HCO- or CHO-

${ }^{6} \mathrm{Bz}$ - is the symbol generally used for benzoyl in organic chemistry. It should not be used for benzyl $\left(\mathrm{C}_{6} \mathrm{H}_{5} \mathrm{CH}_{2^{-}}\right.$or $\left.\mathrm{PhCH}_{2}-\right)$, for which the symbol is Bzl-. However, $\mathrm{PhCH}_{2}$ - is unambiguous.

${ }^{7}$ See Comment following 5.3.

${ }^{8}$ Not succinyl, although it is the univalent radical of succinic acid. See succinyl and footnote 11 .

9 The use of ' $D$ ' for 'di' and ' $T$ ' for 'tri' or 'tetra' (and ' $\mathrm{DH}$ ' and ' $\mathrm{TH}$ ' for 'dihydro' and 'tetrahydro' respectively) is discouraged. Recognized symbols and subscripts are recommended. See also footnote 3 . 


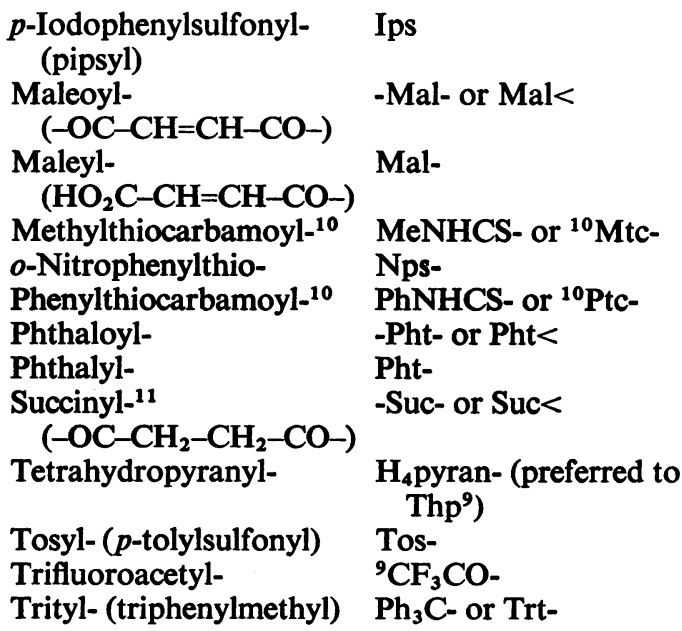

\subsection{Substituents at carboxyl group}

\begin{tabular}{|c|c|}
\hline $\begin{array}{l}\text { Benzyloxy- (benzyl } \\
\text { ester) }\end{array}$ & $-\mathrm{OCH}_{2} \mathrm{Ph}$ or $-\mathrm{OBzl}$ \\
\hline Cyanomethoxy- & $-\mathrm{OCH}_{2} \mathrm{CN}$ \\
\hline $\begin{array}{l}\text { Diphenylmethoxy- } \\
\text { (benzhydryl ester) }\end{array}$ & $-\mathrm{OCHPh}$ or $-\mathrm{OBzh}$ \\
\hline Ethoxy- (ethyl ester) & $-\mathrm{OEt}$ \\
\hline Methoxy- (methyl ester) & $-\mathrm{OMe}$ \\
\hline $\begin{array}{l}p \text {-Nitrophenoxy- } \\
\text { (p-nitrophenyl ester) }\end{array}$ & $-\mathrm{ONp}$ \\
\hline$p$-Nitrophenylthio- & $-\mathrm{SNp}$ \\
\hline $\begin{array}{l}\text { Phenylthio- (phenylthiol } \\
\text { ester) }\end{array}$ & $-\mathrm{SPh}$ \\
\hline $\begin{array}{l}\text { 1-Piperidino-oxy- } \\
\text { 8-Quinolyloxy- } \\
\text { Succinimido-oxy- } \\
t \text {-Butoxy- }(t \text {-butyl ester) }\end{array}$ & $\begin{array}{l}\text {-OPip } \\
\text {-OQu } \\
\text {-ONSu } \\
\text {-OBut }\end{array}$ \\
\hline
\end{tabular}

\section{Comment}

Many reagents used in peptide and protein chemistry for the modification (protection) of amino, carboxyl and side-chain groups in amino-acid residues have been designated by a variety of acronymic abbreviations, too numerous to be listed here. Extensive and indiscriminate use of such abbreviations is discouraged, especially where the accepted trivial name of a reagent is short enough, e.g., tosyl chloride, bromosuccinimide, trityl chloride, dansyl chloride etc., or may be formulated in terms of the group transferred, e.g., ${ }^{9} \mathrm{~N}_{2}$ ph-F instead of

10 The symbol Pth has been used to denote a phenylthiohydantoin (e.g., Pth-Leu). Since this incorrectly implies the substitution of an amino acid by a 'phenylthiohydantoyl' group, it is suggested that the abbreviated symbol for such compounds be of the type CS-Leu-NPh or $\mathrm{PhNCS}-\mathrm{Leu}_{\sqsupset}$ (or Leu $>$ PhNCS in textual material.

${ }^{11}$ Not succinoyl (6).

FDNB for 1-fluoro-2,4-dinitrobenzene, Dns-Cl or dansyl-Cl in place of DNS, ${ }^{9} \mathrm{Nbs}_{2}$ in place of DTNB for 5,5'-dithiobis-(2-nitrobenzoic acid) (Ellman's reagent), $\left(\operatorname{Pr}^{\mathrm{i}} \mathrm{O}\right)_{2} \mathrm{PO}-\mathrm{F}, \operatorname{Pr}_{2}^{\mathrm{i}} P$-F, $\mathrm{iPr}_{2} P-\mathrm{F}$, or Dip-F ${ }^{3,9}$ instead of DFP for diisopropylfluorophosphate. Other commonly used substances that may be expressed more clearly in terms of symbols are MalNEt (instead of NEM) for $N$-ethylmaleimide, Tos-PheCH $\mathrm{Cl}_{2} \mathrm{Cl}$ (instead of TPCK) for L-1-tosylamido-2-phenylethyl chloromethyl ketone, Tos-ArgOMe (instead of TAME) for tosyl-L-arginine methyl ester, $\mathrm{Me}_{3} \mathrm{Si}$ - (instead of TMS-) for trimethylsilyl, $\mathrm{CF}_{3} \mathrm{CO}$ - (instead of TFA) for trifluoroacetyl (see 5.2), $\mathrm{H}_{4}$ furan (instead of THF) etc. (See also footnotes 3 and 9.)

Some additional symbolic terms for substituents (and reagents), as examples, are:

\section{2-Aminoethyl-}

Carbamoylmethyl-

Carboxymethyl-

Chloroethylamine

Ethyleneimine

Chloroacetamide

Chloroacetic acid

p-Carboxyphenylmercuri-

$p$-Chloromercuribenzoate

Diazoacetyl-

Hydroxyethyl-

Ethylene oxide

\section{Polypeptides}

\subsection{Polypeptide chains (5)}

Polypeptides may be dealt with in the same manner as substituted amino acids, e.g.:

$$
\begin{aligned}
\begin{array}{l}
\text { Glycylglycine } \\
N-\alpha \text {-Glutamylglycine }
\end{array} & \begin{array}{l}
\text { Gly-Gly } \\
N-\gamma \text {-Glutamylglycine }
\end{array} \\
\underbrace{}_{\text {Glu }} \text { or Gly } & \\
\text { or Glu } & \text { Gly or Glu(Gly) }
\end{aligned}
$$

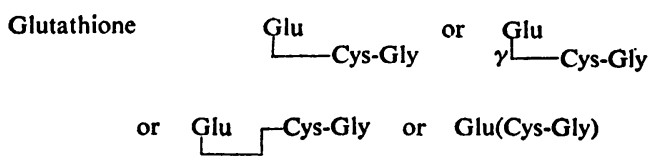

(Note that Glu would represent the correspondCys-Gly 
ing thiol ester with a bond between the $\gamma$-carboxyl of glutamic acid and the thiol group of cysteine.)

$$
\begin{aligned}
& N^{2}-\alpha-\text { Glutamyllysine Glu-Lys } \\
& N^{6}-\alpha-\text { Glutamyllysine Glu } \\
& N^{2}-\gamma \text {-Glutamyllysine }{ }_{\text {Glu }}^{\text {Lys }} \text { or Glu Lys } \\
& N^{6}-\gamma \text {-Glutamyllysine } \begin{array}{l}
\text { Glu or Glu Lys or Glu Lys } \\
\text { Lys }
\end{array}
\end{aligned}
$$

The presence of free, substituted, or ionized functional groups can be represented (or stressed) as follows:

Glycyllysylglycine Its dihydrochloride

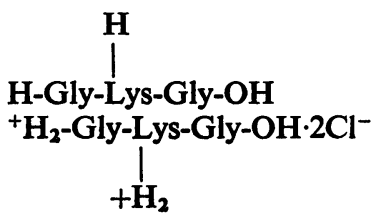

Its sodium salt Its $N^{6}$-formyl derivative Gly-Lys-Gly-O-Na ${ }^{+}$

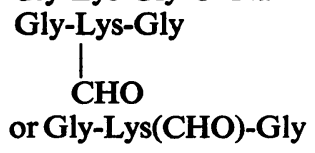

\begin{tabular}{|c|c|}
\hline Glycylnitrosoglycine & Gly $]_{\text {No }}$ Gly or Gly-(NO)Gly \\
\hline Glycylsarcosine (see 2.2.5) & Gly $\underset{\mathrm{Me}}{\text { Gly }}$ or Gly-MeGly \\
\hline & or Gly-Sar \\
\hline$N$-Glycyl- $N$-acetylglycine & Gly $\stackrel{\text { Ac }}{\perp}$ Gly or Gly-(Ac)Gly \\
\hline$N, N$-Diglycylglycine & $\begin{array}{l}\text { Gly__ } \\
\text { Gly__ly }\end{array}$ \\
\hline
\end{tabular}

etc.

\subsection{Peptides substituted at $N^{2}$ (see 4.1)}

\subsection{Cyclic polypeptides}

6.3.1 Homodetic cyclic polypeptides (the ring consists of amino-acid residues in peptide linkage only). Three representations are possible:

6.3.1.1 The sequence is formulated in the usual manner but placed in parentheses and preceded by (an italic) cyclo.
Example:

Gramicidin S

cyclo(-Val-Orn-Leu-D-PhePro-Val-Orn-Leu-D-Phe-Pro-)

or (see 1.5 , sentence 2 )

$$
\begin{aligned}
& \text { cyclo(-Val-Orn-Leu-DPhe- } \\
& \text { Pro-Val-Orn-Leu-DPhe-Pro-) }
\end{aligned}
$$

6.3.1.2 The terminal residues may be written on one line, as in 6.3.1.1, but joined by a lengthened bond. Using the same example in the two forms (see 1.5):

$$
\text { Val-Orn-Leu-D-Phe-Pro-Val-Orn-Leu-D-Phe-Pro }
$$

or

$$
\text { [Val-Orn-Leu-DPhe-Pro-Val-Orn-Leu-DPhe-Pro] }
$$

6.3.1.3 The residues are written on more than one line, in which case the $\mathrm{CO} \rightarrow \mathrm{NH}$ direction must be indicated by arrows, thus (in the optional manner of 1.5):

$$
\left[\begin{array}{l}
\text { Val } \rightarrow \text { Orn } \rightarrow \text { Leu } \rightarrow \text { DPhe } \rightarrow \text { Pro } \\
\text { Pro } \leftarrow \text { DPhe } \leftarrow \text { Leu } \leftarrow \text { Orn } \leftarrow \text { Val }
\end{array}\right]
$$

6.3.2 Heterodetic cyclic polypeptides (the ring consists of other residues in addition to amino-acid residues in peptide linkage). These follow logically from the formulation of substituted amino acids.

Examples:

Oxytocin

$$
\text { Cys-Tyr-Ile-Asn-GIn-Cys-Pro-Leu-Gly-NH }
$$

Cyclic ester of threonylglycylglycylglycine

$$
\text { Thr-Gly-Gly-Gly or H-Thr-Gly-Gly-Gly }
$$

\section{References}

(1) Abbreviated Designation of Amino Acid Derivatives and Peptides: J. Biol. Chem. (1966) 241, 2491; Biochemistry (1966) 5, 2485; Biochim. Biophys. Acta (1966) 121, 1; Biochem. J. (1967) 102, 23; Arch. Biochem. Biophys. (1967) 121, 1; Eur. J. Biochem. (1967) 1, 375; Hoppe-Seyler's Z. Physiol. Chem. (1967) 348, 256; Bull. Soc. Chim. Biol. (1967) 49, 121; Molek. Biol. (1968) 2, 282

(2) Abbreviations and Symbols for Chemical Names of Special Interest in Biological Chemistry (Section 5 revised by 3 below): J. Biol. Chem. (1966) 241, 527; Biochemistry (1966) 5, 1445; Biochem.J. (1966) 101, 1; Virology (1966) 29, 480; Arch. Biochem. Biophys. (1966) 115, 1; Eur. J. Biochem. (1967) 1, 259; HoppeSeyler's Z. Physiol. Chem. (1967) 348, 245; Bull. Soc. Chim. Biol. (1968) 50, 3; Molek. Biol. (1967) 1, 872 
(3) Abbreviations and Symbols for Nucleic Acids, Polynucleotides and their Constituents: Biochem. J. (1970) 120, 449; Biochemistry (1970) 9, 4022; Eur.J. Biochem. (1970) 15, 203; J. Biol. Chem. (1970) 245, 5171; Hoppe-Seyler's Z. Physiol. Chem. (1970) 351, 1055; J. Mol. Biol. (1971) 55, 299; in the press elsewhere

(4) Nomenclature of Vitamins, Coenzymes and Related Compounds: Trivial Names of Miscellaneous Compounds of Importance in Biochemistry, Nomenclature of Quinones with Isoprenoid Side Chains, Nomenclature and Symbols for Folic Acid and Related Compounds, Nomenclature of Corrinoids: Arch. Biochem. Biophys. (1967) 118, 505; Biochem. J. (1967) 102, 15; Biochim. Biophys. Acta (1965) 107, 1;
(1966) 117, 285; Eur. J. Biochem. (1967) 2, 1; J. Biol. Chem. (1966) 241, 2987; Bull. Soc. Chim. Biol. (1967) 49, 331; Hoppe-Seyler's Z. Physiol. Chem. (1967) 348,266

(5) Abbreviated Nomenclature of Synthetic Polypeptides (Polymerized Amino Acids): Biopolymers (1969) 8, 161 ; Arch. Biochem. Biophys. (1968) 123, 633; Biochem. J. (1968) 106, 577; Biochemistry (1968) 7, 483; Biochim. Biophys. Acta (1968) 168, 1 ; Eur. J. Biochem. (1968) 3, 129; J. Biol. Chem. (1968) 243, 2451 ; Bull. Soc. Chim. Biol. (1969) 51, 205; Hoppe-Seyler's Z. Physiol. Chem. (1969) 349, 1013 (Revision in the press)

(6) IUPAC: Nomenclature of Organic Chemistry (Definitive Rules for Section C), Rule C-404 and Table VI: Pure Appl. Chem. (1965) 11, nos. 1-2

All Tentative Rules and Proposals of the IUPAC-IUB Commission on Biochemical Nomenclature (CBN) are available from Waldo E. Cohn, Director, NAS-NRC Office of Biochemical Nomenclature, Oak Ridge National Laboratory, P.O. Box Y, Oak Ridge, Tenn. 37830, U.S.A.:

1. Abbreviations and Symbols for Chemical Names of Special Interest in Biological Chemistry. Revised Tentative Rules [see Biochem. J. (1966) 101, 1-7 (but see item 11 below)].

2. Nomenclature of Vitamins, Coenzymes and Related Compounds: Trivial Names of Miscellaneous Compounds of Importance in Biochemistry, Nomenclature of Quinones with Isoprenoid Side Chains, Nomenclature and Symbols for Folic Acid and Related Compounds, Nomenclature of Corrinoids. Tentative Rules [see Biochem. J. (1967) 102, 15-22 (but see item 10 below)].

3. Abbreviated Designation of Amino Acid Derivatives and Peptides. Tentative Rules [see Biochem. J. (1967) 102, 23-27 (but see item 15 below)].

4. Rules for Naming Synthetic Modifications of Natural Peptides. Tentative Rules [see Biochem. J. (1967) 104, 17-19].

5. The Nomenclature of Lipids. A Document for Discussion [see Biochem. J. (1967) $105,897-902]$.

6. Abbreviated Nomenclature of Synthetic Polypeptides (Polymerized Amino Acids) [see Biochem. J. (1968) 106, 777-579 (revision in the press)].

7. The Nomenclature of Cyclitols. Tentative Rules [see Biochem. J. (1969) 112, 17-28].

8. A One-Letter Notation for Amino Acid Sequences. Tentative Rules [see Biochem.J. (1969) 113, 1-4].

9. Revised Tentative Rules for Nomenclature of Steroids [see Biochem. J. (1969) 113, 5-28].

10. Nomenclature of Vitamins $\mathbf{B}_{6}$ and Related Compounds. Tentative Rules [see Biochem. J. (1970) 119, 1-4 (replaces M7 of item 2 above)].

11. Abbreviations and Symbols for Nucleic Acids, Polynucleotides and their Constituents. Recommendations [see Biochem. J. (1970) 120, 449-454 (replaces section 5 of item 1 above)].

12. Abbreviations and Symbols for the Description of the Conformation of Polypeptide Chains. Tentative Rules [see Biochem. J. (1971) 121, 577-585].

13. Tentative Rules for Carbohydrate Nomenclature: Part 1 [see Biochem. J. (1971) 125, 673-695].

14. The Nomenclature of Multiple Forms of Enzymes [see Biochem. J. (1972) 126, 769-771].

15. Symbols for Amino Acid Derivatives and Peptides. Recommendations [this document (revision of item 3 above)].

A document, OBN-5, describing the (American) NAS-NRC Office of Biochemical Nomenclature, and listing other rules affecting biochemical nomenclature, is available from its Director, Dr. Waldo E. Cohn [see also J. Chem. Doc. (1967) 7, 72-73; (1969) 9, 235-241]. 